\title{
NADPH-Cytochrome P450 Reductase
}

National Cancer Institute

\section{Source}

National Cancer Institute. NADPH-Cytochrome P450 Reductase. NCI Thesaurus. Code C16890.

NADPH-cytochrome P450 reductase (677 aa, $77 \mathrm{kDa}$ ) is encoded by the human POR gene. This protein plays a role in electron transfer. 